\title{
Radiation levels of UV-A and UV-B on growth parameters and coumarin content in guaco
}

\section{Luciano Alves $^{1 *}$ (D) Cícero Deschamps ${ }^{2}$}

${ }^{1}$ Instituto Federal Catarinense, Campus Araquari, 89245-000, Araquari, SC, Brasil. E-mail: luciano.alves@ifc.edu.br. "Corresponding author. ${ }^{2}$ Universidade Federal do Paraná (UFPR), Setor de Ciências Agrárias, Curitiba, PR, Brasil.

ABSTRACT: Guaco is a medicinal plant species containing coumarin, a secondary metabolite whose concentration is influenced by various factors, such as the level of exposure to UVA $(315-400 \mathrm{~nm})$ and UVB $(280-315 \mathrm{~nm})$ radiation, age of the plant, and position of the storage organ in the plant. This study aimed to assess the effect of different blocking levels of UVA and UVB radiation on growth parameters and coumarin content of two guaco accessions. Treatments did not affect any of the growth parameters assessed, except leaf area. Coumarin content was higher in leaves collected from the upper canopy and with unblocked exposure to UVA and UVB.

Key words: Mikania glomerata Spreng; 1-2-benzopyrone; secondary metabolism; growth analysis; environmental factors.

Níveis de radiação UVA e UVB sobre parâmetros de crescimento e conteúdo de cumarina em guaco

RESUMO: Guaco é uma espécie medicinal que apresenta em sua composição a cumarina, um metabólito secundário cuja concentração no vegetal é influenciada por fatores como os niveis de radiação UV-A (315-400 nm) e UV-B (280-315 nm) incidentes, bem como pela idade e posição do órgão de armazenamento na planta. O objetivo deste estudo foi o de avaliar o efeito de diferentes níveis de bloqueio das radiações $U V$-A e UV-B sobre parâmetros de crescimento e teor de cumarina em dois acessos de guaco. Os tratamentos não apresentaram efeito sobre os parâmetros de crescimento avaliados, com exceção dos valores de área foliar. Em relação aos teores de cumarina, estes foram superiores nas folhas coletadas do dossel superior, bem como no tratamento sem bloqueio das radiações $U V$ - $A$ e $U V$-B incidentes.

Palavras-chave: Mikania glomerata Spreng, 1-2-benzopirona, metabolismo secundário, análise de crescimento, fatores ambientais.

\section{INTRODUCTION}

The genus Mikania, in the family Asteraceae, comprises approximately 450 species, of which 150 are reported in Brazil. This genus includes Mikania glomerata Spreng, a medicinal species popularly known as guaco, which has been used for centuries in folk medicine to produce medications intended to treat cough and respiratory problems (MATSUSHITA et al., 2015).

Medicinal properties of this species can be attributed to the presence of coumarins (1-2-benzopyrones) in the plant. Coumarins are a class of secondary metabolites formed via the shikimic acid pathway by the condensation of two glucose metabolites, namely, phosphoenolpyruvate and erythrose-4-phosphate (CZELUSNIAK et al., 2012).

Secondary metabolites constitute a chemical interface between plants and the environmental conditions to which they are exposed; therefore, their synthesis is influenced by factors, such as exposure to ultraviolet $A$ (UVA, 315-400 nm) and ultraviolet B (UVB, 280-315 nm) radiation, which can affect growth parameters and change the composition of secondary metabolites (BEJERANO et al., 2014; PETRUL'OVÁ et al., 2014).

The use of plastic covers, which are capable of blocking various levels of incident UVA and UVB radiation, is an alternative to investigate and stimulate the effects of UV radiation on the synthesis of secondary metabolites that are found in low concentrations in plants, i.e., approximately $1 \%$ of the plant's total dry mass (MORMILE et al., 2017).

This study aimed to assess the effect of different blocking levels of UVA and UVB radiation on the growth parameters and coumarin content of two guaco (M. glomerata Spreng) accessions. 


\section{MATERIALS AND METHODS}

Two guaco (M. glomerata Spreng) accessions, named G1 and G2, were used, with their exsiccates deposited in the herbarium of the Museum Botanical Gerdt Hatschbach in the municipal of Curitiba, Brazil, under numbers 367612 and 340947.

Saplings for planting were obtained by the cutting technique. Cuttings containing a node were obtained from two-year-old stock plants by making a bezel-shaped cut in the base and a straight cut above the last apex bud. These cuttings were approximately $10 \mathrm{~cm}$ long, and two leaves were kept in the apex region with the area reduced by half. Cuttings were disinfected by immersion in a $0.5 \%$ sodium hypochlorite solution for five minutes, followed by washing in running water for two minutes. The bases of the cuttings were treated with indole-butyric acid (IBA) in a $3000 \mathrm{ppm}$ solution in $50 \%$ alcohol for 15 seconds.

Rooting was performed by planting cuttings in grow bags for saplings measuring $10 \times 18 \mathrm{~cm}$, containing Carolina ${ }^{\circledR}$ commercial substrate, composed of sphagnum peat moss, expanded vermiculite, dolomite lime, agricultural gypsum, and traces of NPK fertilizer. Cuttings were kept in a misting tunnel ( $80 \%$ relative humidity) for 45 days and acclimatized under Sombrite ${ }^{\circledR}$ (40\%) shade cloth for 10 days, followed by exposure to direct sunlight for another 10 days before definitive planting, which was done in 5 liter polyethylene vases with the volume topped with soil.

The soil used was classified as a humicorthic quartzenic neosol. It was collected from the arable layer $(0-20 \mathrm{~cm})$ and sieved prior to planting using a no. 55 bean sieve. Its chemical characteristics were as follows: $\mathrm{CaCl}_{2} \mathrm{pH}, 5.7$; ShoemakerMcLean-Pratt (SMP) $\mathrm{pH}, 6.0 ; \mathrm{Al}^{3+}, 0.0 \mathrm{mmol}_{\mathrm{c}} \mathrm{dm}^{-3}$; $\mathrm{H}^{+}+\mathrm{Al}^{3+}, 43 \mathrm{mmol} \mathrm{dm}^{-3} ; \mathrm{Ca}^{2+}, 62 \mathrm{mmol} \mathrm{\textrm {dm } ^ { - 3 }} ; \mathrm{Mg}^{+}$, $14 \mathrm{mmol} \mathrm{dm}_{\mathrm{c}}^{-3}$; $\mathrm{K}^{+}, 2.2 \mathrm{mmol}_{\mathrm{c}} \mathrm{dm}^{-3}$; sum of bases (SB), $78.2 \mathrm{mmol}_{\mathrm{c}} \mathrm{dm}^{-3}$; cation exchange capacity (T), $121.2 \mathrm{mmol}_{\mathrm{c}} \mathrm{dm}^{-3}$; P, $195 \mathrm{mg} \mathrm{dm}^{-3}$; C, $37.4 \mathrm{~g} \mathrm{dm}^{-3}$; base saturation ( $\mathrm{V} \%$ ), 65; and $\mathrm{Ca} / \mathrm{Mg}$ ratio, 4.43 .

The experiment design was completely randomized, arranged in a $2 \times 3$ factorial of treatments comprising two guaco accessions and three radiation exposures. Four repetitions were made for each treatment, and each repetition comprised the mean values of four plants.

Radiation exposure treatments were conducted in $60 \mathrm{~cm}$ high tunnels, totally sealed with $150-\mu \mathrm{m}$ thick plastic film, blocking radiation at the following levels: $100 \%$ of both UVA and UVB radiation (100\% UVA/B); $70 \%$ of UVA and $80 \%$ of UVB radiation (70\% UVA $/ 80 \%$ UVB). A control treatment was also conducted with no blocking of UVA or UVB radiation ( $0 \%$ UVA/ $0 \%$ UVB).

The experiment was conducted in the municipality of Araquari, in the Northeastern region of the state of Santa Catarina, Brazil, for 55 days, which is the time required for most plants to reach the height of the tunnels that were used in the radiation blocking treatments.

After the execution period, the following variables were analyzed: height of the aerial part $(\mathrm{cm})$, leaf area $\left(\mathrm{cm}^{2}\right)$, dry mass of leaves and branches (g), total dry mass (g), and coumarin content of the apical, middle, and basal segments of the plant tissue $\left(\mathrm{mg} \mathrm{g}^{-1}\right)$. Plant segments were defined by dividing the plant height into three equal parts.

Leaf area was determined using the leaf disc method, according to the procedures described by FERNANDES (2000).

For determining coumarin content, leaves were collected from the apical, middle, and basal segments. After removing the petiole, leaves were fragmented, and the resulting fragments were passed through an 8-mesh sieve (opening of $2.36 \mathrm{~mm}$ ). Samples of the plant material weighing $0.2 \mathrm{~g}$ were placed into centrifuge tubes containing $25 \mathrm{~mL}$ of methanol P.A.

Coumarin content of the extracts was determined by high-performance liquid chromatography, using a technique adapted from MEDEIROS \& KANIS (2010).

Results were subjected to an analysis of variance. First, the variances of the treatments were tested for homogeneity using Bartlett's test. Then, the variables shown to have homogeneous variance underwent an Ftest of their effects in an analysis of variance. When the results showed that there were statistically significant differences between the means of the treatments, the means were compared using Tukey'stest at 5\% probability, using Statgraphics Centurion XV statistical software, version 15.2.11.

\section{RESULTS AND DISCUSSION}

Although, no significant differences were observed between the radiation blocking levels with respect to plant height $(\mathrm{cm})$ and total dry mass $(\mathrm{g})$ of branches and leaves, a significant difference was observed between the leaf areas $\left(\mathrm{cm}^{2}\right)$ of accessions G1 and G2 (Table 1).

Several studies have previously reported regarding the differences in the growth pattern of plant species according to the sources and levels of UV 
Table 1 - Mean results for height $(\mathrm{cm})$, leaf area $\left(\mathrm{cm}^{2}\right)$, dry mass $(\mathrm{g})$ of branches and leaves, and total dry mass $(\mathrm{g})$ of guaco $($ Mikania glomerata Spreng) accessions subjected to different blocking levels of incident UV-A and UV-B radiation.

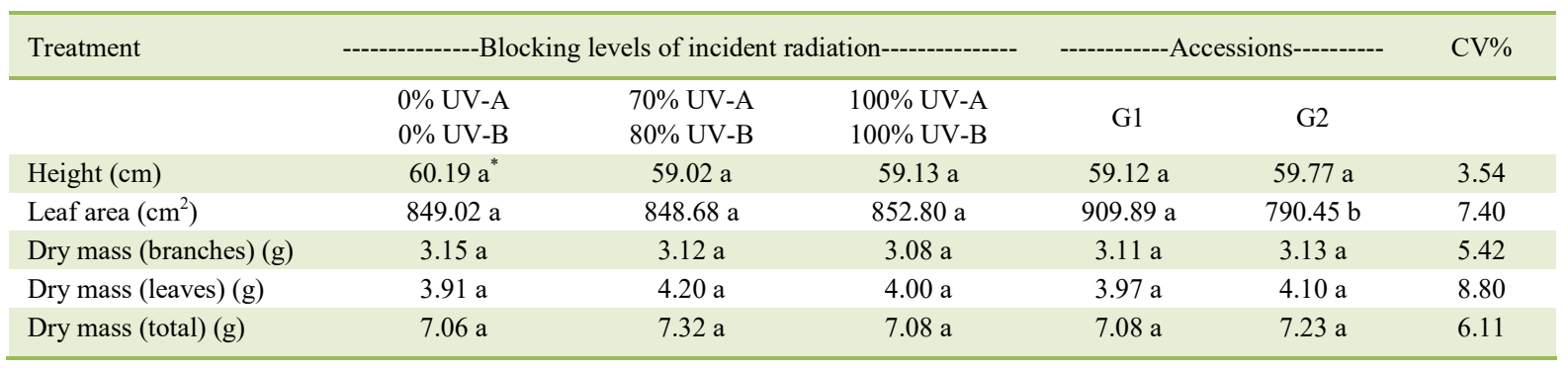

*Means that are not followed by the same letter in a line are significantly different according to Tukey’s test ( $\mathrm{p}<0.05$ ).

radiation to which they are exposed. AMUDHA et al. (2005) observed that the suppression of UVA and UVB radiation resulted in different responses in the studied species. The Cyamopsis tetragonoloba showed an increase in vegetative growth, whereas no effect and decrease in growth were observed in Vigna radiate and $V$. mungo, respectively. JUNIOR et al. (2009), in an experiment studying the effect of luminosity on the structural variations of $M$. glomerata leaves, observed that the highest leaf area values were obtained in plants grown under low-light conditions.

As a rule, plants grown in places with low UV radiation levels accumulate more biomass in the leaves and exhibit higher leaf area values. By contrast, plants grown in places exposed to intense sunlight show greater development of the root system, to compensate for the water losses caused by transpiration (BOEGER et al., 2009). In the present study, the differences observed between the leaf area values of accessions G1 and G2 may be related to morphological or even physiological characteristics of the accessions studied.

An interaction was observed between radiation intensity and coumarin content in different plant segments of guaco accessions (Table 2).

When the effects of UVA and UVB radiation on coumarin synthesis in the apical, middle, and basal segments was analyzed, a reduction in these values is observed as radiation blocking levels increase: $11 \%$ for the apical segment, $32 \%$ for the middle segment, and $39 \%$ for the basal segment.

Several studies have reported a positive correlation between UV radiation levels and the synthesis of secondary metabolites, more specifically of phenolic compounds. This is because these compounds, especially flavonoids, are photoprotective, preventing damage to plant tissues caused particularly by UVB radiation (RANDRIAMANANA et al., 2015).

In a study assessing the influence of UVB radiation on coumarin production in Clematis terniflora, YANG et al. (2016) observed that the exposure of this species to high levels of UVB radiation stimulated coumarin synthesis at concentrations that were two times higher than those of plants grown in shade conditions. Those authors inferred that this induction could be related to the synthesis of proteins that play a direct role in phenylpropanoid synthesis.

YAO et al. (2015) assessed the protective functions of ascorbate and tocopherol in leaves of Arabidopsis thaliana mutants exposed to different levels of UVB radiation and the influence of UVB radiation on carotenoid and phenylpropanoid synthesis. Increased phenylpropanoid synthesis was observed when plants were exposed to high levels of UVB radiation.

The opposite effect; i.e, an inhibition of phenylpropanoid synthesis and; consequently, low coumarin content, could explain results obtained after exposure of guaco accessions to filters capable of blocking a large part of the incident UVA and UVB radiation.

When coumarin content ( $\mathrm{mg} \mathrm{g}^{-1}$ ) was compared disregarding the difference between the accessions used, higher results are observed with respect to the synthesis of the compound in the leaves of the apical segment of guaco plants (Table 2).

Coumarin content significantly varies in guaco leaves; with the highest content in young leaves close to the apex bud, indicating that the meristem region is the most likely site of synthesis. This also suggested that there is a relationship between coumarin content and plant growth and development processes (CZELUSNIAK et al., 2012; RADÜNZ et al., 2012). 
Table 2 - Mean results for coumarin content $\left(\mathrm{mg} \mathrm{g}^{-1}\right)$ in different segments of guaco (Mikania glomerata Spreng) accessions subjected to different blocking levels of incident UV-A and UV-B radiation.

\begin{tabular}{|c|c|c|c|c|}
\hline \multirow[t]{2}{*}{ Plant segment } & \multirow[t]{2}{*}{ Blocking levels of incident radiation } & \multicolumn{2}{|c|}{ 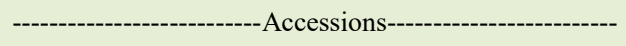 } & \multirow[t]{2}{*}{$\mathrm{CV} \%$} \\
\hline & & G1 & G2 & \\
\hline \multirow{3}{*}{ Apical } & $0 \% \mathrm{UV}-\mathrm{A} / 0 \% \mathrm{UV}-\mathrm{B}$ & $6.19 \mathrm{a} \mathrm{A}^{*}$ & $4.21 \mathrm{a} \mathrm{B}$ & 20.60 \\
\hline & $70 \%$ UV-A $/ 80 \%$ UV-B & $5.61 \mathrm{~b} \mathrm{~A}$ & 4.10 a B & 22.65 \\
\hline & $100 \% \mathrm{UV}-\mathrm{A} / \mathrm{B}$ & $5.24 \mathrm{~b} \mathrm{~A}$ & $4.05 \mathrm{a} B$ & 23.84 \\
\hline \multirow{3}{*}{ Middle } & $0 \%$ UV-A $/ 0 \%$ UV-B & 5.86 a A & $3.67 \mathrm{a} B$ & 26.06 \\
\hline & $70 \%$ UV-A $/ 80 \%$ UV-B & $4.39 \mathrm{~b} \mathrm{~A}$ & $3.23 \mathrm{a} \mathrm{B}$ & 22.25 \\
\hline & $100 \% \mathrm{UV}-\mathrm{A} / \mathrm{B}$ & $4.00 \mathrm{~b} \mathrm{~A}$ & $2.51 \mathrm{~b} \mathrm{~B}$ & 29.27 \\
\hline \multirow{3}{*}{ Basal } & $0 \%$ UV-A/0\% UV-B & 4.54 a A & 2.64 a B & 29.56 \\
\hline & $70 \% \mathrm{UV}-\mathrm{A} / 80 \% \mathrm{UV}-\mathrm{B}$ & $2.62 \mathrm{~b} \mathrm{~A}$ & $2.24 \mathrm{~b} \mathrm{~A}$ & 22.06 \\
\hline & $100 \% \mathrm{UV}-\mathrm{A} / \mathrm{B}$ & $2.76 \mathrm{~b} \mathrm{~A}$ & $1.60 \mathrm{c} \mathrm{B}$ & 28.00 \\
\hline
\end{tabular}

${ }^{*}$ Means within the same plant segment that are not followed by the same lowercase letter in a column and the same uppercase letter in a line are significantly different according to Tukey's test $(\mathrm{p}<0.05)$.

In addition, the leaves of the upper canopy are subjected to a greater interference from light energy, and according to GONÇALVES et al. (2003), there is a highly significant correlation between light intensity and production of secondary metabolites, because light affects the photosynthesis process in plants and is closely related to the synthesis of all substances present in plants.

This statement agrees with the results obtained by PEREIRA et al. (2000) in a study assessing the effect of seasonal variation on the coumarin content of guaco plants. Those authors reported that the age of the plant influences the coumarin content and the highest content was reportd in young leaves close to the apex of the branch.

Similar results were obtained by CASTRO et al. (2006), who assessed the behavior of guaco plants grown under full sunlight and observed that the highest coumarin content was reported in young leaves located close to the apex of the plant.

Results of that study supported those of our experiment, as during the period of execution, between October and December 2015, the mean precipitation value was $2.90 \mathrm{~mm} /$ day and mean daily sunlight time was 8.6 hours/day.

When the accessions of $M$. glomerata Spreng were compared without considering the plant segments, a statistically significant difference of $32 \%$ was observed between the mean coumarin content of accessions G1 and $\mathrm{G} 2$ (4.58 and $3.14 \mathrm{mg} \mathrm{g}^{-1}$ ) respectively.

Accession G1 presented higher leaf area values than accession $\mathrm{G} 2$, indicating a higher metabolic activity of accession G1. This could ultimately explain the higher coumarin content in the plant tissue of accession G1 than in that of accession G2 (YAO et al., 2015).

\section{CONCLUSION}

Exposure to UVA and UVB radiation affected coumarin content and leaf area values of the guaco accessions that were studied. The highest coumarin content was observed in young leaves located close to the apex of the plant, a region which is considered to be a site for coumarin synthesis. Accession G1 presented higher leaf area values, which contributed to a greater metabolic activity and consequently to its higher coumarin content than that of accession $\mathrm{G} 2$.

\section{ACKNOWLEDGMENTS}

The authors wish to thank the Brazilian government's Coordination for the Improvement of Higher Education Personnel (CAPES) and the Catarinense Federal Institute (IFC) for the financial support and scholarships they provided.

\section{DECLARATION OF CONFLICT OF INTERESTS}

The authors declared no potential conflicts of interest with respect to the research, authorship, and/or publication of this article.

\section{AUTHORS' CONTRIBUTIONS}

All authors contributed equally for the conception and writing of the manuscript. All authors critically revised the manuscript and approved of the final version. 


\section{REFERENCES}

AMUDHA, P. et al. Impacts of ambient solar UV (280-400 nm) radiation on three tropical legumes. Journal of Plant Biology, v.48, n.3, p.284-291, Sep. 2005. Available from: <https://doi. org/10.1007/BF03030524>. Accessed: Oct. 13, 2017. doi: $10.1007 / \mathrm{BF} 03030524$

BEJERANO, P.C. et al. Solar ultraviolet radiation is necessary to enhance grapevine fruit ripening transcriptional and phenolic responses. BMC Plant Biology, v.14, n.1, p.78-93, Jul. 2014. Available from: <https://doi.org/10.1186/1471-2229-14-183>. Accessed: Sep. 26, 2017. doi: 10.1186/1471-2229-14-183.

BOEGER, M.R.T.; et al. Variação estrutural foliar de espécies medicinais em consórcio com erva-mate, sob diferentes intensidades luminosas. Floresta, v.39, n.1, 2009. Available from: $<$ http://dx.doi.org/10.5380/rf.v39i1.13741>. Accessed: Dec. 09, 2018. doi: 10.5380/rf.v39i1.13741.

CASTRO, E.M.; et al. Coumarin contents in young Mikania glomerata plants (Guaco) under different radiation levels and photoperiod. Acta Farmaceutica Bonaerense, v.25, n.3, p.387, 2006. Available from: <http://www.latamjpharm. org/trabajos/25/3/LAJOP $25 \quad 3 \quad 1 \quad 11$ 4ATY7SMOC9.pdf>. Accessed: Dec. 8, 2018.

CZELUSNIAK, K.E. et al. Farmacobotânica, fitoquímica e farmacologia do Guaco: revisão considerando Mikania glomerata Sprengel e Mikania laevigata Schulyz Bip. ex Baker. Revista Brasileira de Plantas Medicinais, v.14, n.2, p.400409, 2012. Available from: <https://dx.doi.org/10.1590/S151605722012000200022>. Accessed: Sep. 26, 2016. doi: 10.1590/ S1516-05722012000200022.

FERNANDES P.D. Análise de crescimento e desenvolvimento vegetal. Campina Grande: UFPB. 2000. 22p.

GONÇALVES, L.A.; BARBOSA, L.C.A.; AZEVEDO, A.A.; CASALI, V.W.D.; NASCIMENTO, E.A. Produção e composição do óleo essencial de alfavaquinha (Ocimum selloi Benth.) em resposta a dois níveis de radiação solar. Revista Brasileira de Plantas Medicinais, Botucatu, v.6, n.1, p.8-14, 2003. Available from: <http://www.sbpmed.org.br/download/issn_03_2/artigo2 v6 n1.pdf $>$. Accessed: Dec. 03, 2018.

JUNIOR, A.E.; BOEGER, M.R.T.; JÚNIOR, A.M.; REISSMANN, C.B.; RICKLI, F.L.Variação na estrutura foliar de Mikania glomerata Spreng.(Asteraceae) sob diferentes condições de luminosidade. Revista Brasileira de Botânica, v.32, n.4, p.749758, 2009. Available from: <http://www.scielo.br/pdf/rbb/v32n4/ a13v32n4>. Accessed: Dec. 05, 2018.

MATSUSHITA, M.S. et al. Produção e comercialização do guaco (Mikania laevigata Schultz Bip. ex Baker) na região sul do estado do Paraná. Revista Brasileira de Plantas Medicinais, v.17, n.3, p.351-359, Jul./Set. 2015. Available from: <https://dx.doi.
org/10.1590/1983-084X/11_154>. Accessed: Aug. 25, 2017. doi: 10.1590/1983-084X/11_154.

MEDEIROS, J.; KANIS, L.A. Avaliação do efeito de polietilenoglicóis no perfil de extratos de Mikania glomerata Spreng., Asteraceae, e Passiflora edulis Sims, Passifloraceae. Revista Brasileira de Farmacognosia, v. 20, n. 5, p. 796802, 2010. Available from: <https://dx.doi.org/10.1590/S0102695X2010005000001>. Accessed: Oct. 07, 2015. doi: 10.1590/ S0102-695X2010005000001.

MORMILE, P.; STAHL, N.; MALINCONICO, M. The World of Plasticulture. In: Soil Degradable Bioplastics for a Sustainable Modern Agriculture. Springer, Berlin, Heidelberg, 2017. p. 1-21.

PEREIRA, A.M.S.; CÂMARA, F.L.A.; CELEGHINI, R.M.S.; VILEGAS, J.H.Y.; LANÇAS, F.M.; FRANÇA, S.C. Seasonal variation in coumarin content of Mikania glomerata. Journal of Herbs, Spices \& Medicinal Plants, Vol.7, n.2, 2000. Available from: <https://doi.org/10.1300/J044v07n02_01>. Accessed: Dec. 08, 2018. doi: 10.1300/J044v07n02 01 .

PETRULOVÁ, V. et al. Short-term UV-B dose stimulates production of protective metabolites in Matricaria chamomilla Leaves. Photochemistry and Photobiology, v.90, n.5, p.1061-1068, Aug. 2014. Available from: <https://dx.doi.org/10.1111/php.12300>. Accessed: Jan. 14, 2018. doi: 10.1111/php.12300.

RADÜNZ, L. L.; MELO, E. C.; BARBOSA, L. C. A.; ROCHA, R. P.; BERBERT, P. A. Rendimento extrativo de cumarina de folhas de guaco (Mikania glomerata Sprengel) submetidas a diferentes temperaturas de secagem. Revista Brasileira de Plantas Medicinais, Botucatu, v.14, n.3, p.453-457, 2012. Available from: $<$ https://doi.org/10.1590/S1516-05722012000300005>. Accessed: Dec. 12, 2018. doi: 10.1590/S1516-05722012000300005.

RANDRIAMANANA, T.R. et al. Interactive effects of supplemental UV-B and temperature in european aspen seedlings: Implications for growth, leaf traits, phenolic defense and associated organisms. Plant Physiology and Biochemistry, v.93, n.1, p.84-93, Aug. 2015. Available from: $<$ https://dx.doi.org/10.1016/j.plaphy.2015.03.001>. Accessed: Sep. 23, 2017. doi: 10.1016/j.plaphy.2015.03.001.

YANG, B., WANG, X., GAO, C., CHEN, M., GUAN, Q., TIAN, J., KOMATSU, S. Proteomic and metabolomic analyses of leaf from Clematis terniflora DC. exposed to high-Level ultraviolet-B irradiation with dark treatment. Journal of proteome research, v.15, n.8, p.2643-2657, 2016. Available from: <https://pubs.acs. org/doi/pdf/10.1021/acs.jproteome.6b00206>. Accessed: Dec. 08, 2018. doi: 10.1021/acs.jproteome.6b00206.

YAO, Y. et al. Ultraviolet-b protection of ascorbate and tocopherol in plants related with their function on the stability on carotenoid and phenylpropanoid compounds. Plant Physiology and Biochemistry, v.90, n.1, p.23-31, May. 2015. Available from: $<$ https://dx.doi.org/10.1016/j.plaphy.2015.02.021>. Accessed: Jun. 09, 2017. doi: 10.1016/j.plaphy.2015.02.021. 